\title{
「知的な機械・システム」と責任に関する意識 Perception of the Roles of Intelligent Machines and Systems
}

\author{
荒井 弘毅 \\ Koki Arai \\ 秀明大学総合経営学部 \\ Faculty of Management and Administration, Shumei University. \\ arai@mailg.shumei-u.ac.jp, http://www.shumei-u.ac.jp
}

Keywords: Intelligent Machines and Systems, Recognition, Responsibility

\section{Summary}

In this paper, we analyzed individuals' perceptions of the roles of intelligent machines and systems based on the results of a questionnaire survey conducted in 2015 and 2016 on artificial intelligence, robots, and other "intelligent machines and systems." In conclusion, 1) human labor was not strongly supported for so-called public goods and services such as disaster prevention and military jobs, rather than leaving these tasks to machines. 2) In support of existing research, child-rearing was seen as women's responsibility as in the present situation, considering that women and children benefit from the parenting experience. In addition, university graduates with high flexibility for social option and creative capacity are perceived to benefit from human-powered jobs, especially in tasks that require human responsibility or where the cost of implementing intelligent machines and systems would be expensive. Also, some tasks, such as music, are viewed as preferentially human tasks. 3) After taking into consideration endogenous in the regression, such as for child rearing and nursing care, overall, individuals perceived that childcare should not be left to machines, although nursing care was considered to possibly benefit from the use of machines.

\section{1. はじめに}

今日，人工知能をはじめとする情報技術が進展し，社 会に影響を及ぼしつつある. 2016 年 1 月に閣議決定され た日本の第 5 期科学技術基本計画においても「超スマー 卜社会」実現のための様々なステークホルダーによる対 話・協㗢に触れている，こうした背景の下，多様なステ ークホルダーに人工知能と社会に関する意識調査を行う ことで対話のベースラインとなる知見を提供することを 目的として, 国立研究開発法人科学技術振興機構 (JST) 社会技術研究開発センター（RISTEX）と Acceptable Intelligence with Responsibility (AIR)の共同研究として, 超 スマート社会の社会受容性調査, 一般モニタアンケート 調査が 2015 年 12 月及び 16 年 12 月に行われている. そ こでは，技術を社会と分離したものとするのではなく相 互作用して社会規範も変化していくものとして, 近未来 における現在の延長上にある技術を調査対象とし，人の 状態や希望を自動で察知・判断し, 先回りして必要な情 報などを提供するサービスを「知的な機械・システム」 と定義し，これに対する人々の意識，研究開発の方向性 や研究者への信頼, 技術に対する認識を調べている[江間 16a].

高度情報社会における社会規範を議論する際の一つ
の鍵として責任概念が挙げられる．責任概念を議論する 際には, 複雑化し多様化する責任主体を法, 思想等様々 な観点から整理することが必要である。これとともに， 今日まで提起されてきた責任概念を参照軸として用いる ことで, 今後の責任概念の変貌を予測することができる.

こうした努力を継続して続けることによって，情報技術 の専門家の研究活動と将来的な技術進展の円滑な展開を 支える文化的で社会的な責任概念基盤を提言することが 可能になると考えられる. 人工知能学会倫理指針 [人工知 能学会倫理委員会 17]においても，序文において「人工 知能研究者は, 社会の様々な声に耳を傾け, 社会から謙 虚に学ばなければならない.人工知能研究者は技術の進 化及び社会の変化に伴い，人工知能研究者自身の倫理観 を発展させ深めることについて不断の努力をおこなう」 ことが明記されている。この不断の努力を続けていくた めには，人文学的アプローチによる過去の責任概念の整 理や現段階で認識されている人工知能を含む知的な機 械・システムに対する責任概念を検討していくことで責 任概念自体が持つ多様性と歴史性を把握することが重要 だと考えられる，そして，それに基づき，また倫理指針 を踏まえた上で, 高度情報社会における責任概念の今日 的な意味を模索することが必要とされている.

こうした観点において，本稿は，高度情報社会におけ 
る責任概念に関して，「知的な機械・システム」への態度 と認識の実態を示すことで人工知能の倫理を考える材料 を提供するものである，なお，本稿では，義務感や倫理 的・法的責任, そして責任帰属意識を包括した意味で責 任概念についての認識を検討対象とするものであり，い わゆる法的責任ではなく倫理的責任を取り上げるもので ある。

\section{2. 責任概念に関する先行研究}

責任の帰属に関しては, 自己の心理学的な安寧を維持 しょうとする自己防衛的動機付けを仮定する防衛的帰属 理論がある，これは，自己防衛的動機付けに基づく帰属 上のバイアスに注目し，一見したところでは原因が不明 確である偶然の事故に関して，その重大性に依存寸る責 任帰属概念の仮説が提起されている[諸井 88, Walster 66]. すなわち, 結果が些細なものであるときには当事者に同 情し偶然性に原因を帰属するが，その結果が重大である ときにはそのような事故生起から自己を心理的に防衛す るために当事者に大きい責任を帰属するとするものであ る.これに対して，1）自らも後で適用される可能性のあ る厳しい道義的基準を当事者に課すのは自己防衛的傾向 と矛盾する. 2) 判断者にも生じ得る事故に直面したとき に自己防衛的傾向が生じると批判が加えられ, 関連性概 念が提起されている[Shaver 70]. これは, 当事者と判断者 との環境条件間の類似性を意味する状況的関連性と，何 らかの個人的特徴での類似性を意味する個人的関連性と を区別し，1）状況的関連性が高いときにの久自己防衛的 動機付けが喚起される. 2) 当事者と判断者との間に何ら かの個人的関連性があるときには非難回避（blame avoidance）のために偶然性に対して，そのような関連性 がないときには危害回避（harm avoidance）のためその当 事者に対して，それぞれ，帰属がなされるとするもので ある.これらは更に多様な検討が行われ，1)事故の結果 の重大さと責任帰属との間に結果がネガティブな場合に は正の関係・結果がポジティブな場合には負の関係を見 いだす．2)認知的务威が偶然性への帰属を抑制するよう に方向付けているとする. 3)事故の構造・当事者の立場・ 生起頻度が影響を及ぼしているとする。4)その他結果の 予見可能性, 責任判断の次元 (主観的- 客観的判断), 当 事者の特徴（魅力・事前の注意 - 先行経験 - 努力能力意 図性), 個人的傾性（性役割観，道徳的発達水準）等の関 係を見るものなど, 様々な分析がなされている[諸井 03].

これらは近年の研究でも, 強盗・殺人被害の場面にお ける, 被告者に帰属されるラベルの分析においては責任 がもっとも低く評定され, 次いで落ち度, 隙の順となっ たことを示すものがある[白岩 12]. また, 経済的格差問 題, とりわ㥧困の政策的是正に対して人々が持ってい る態度について機会の平等性に関わる認知と責任帰属判 断を検討し, 責任帰属認知は, 機会統制可能認知によっ
て規定されていて，教育ないし就業の機会の個人的統制 可能性が高いと見積もられるほど政府への責任帰属は減 少し, 貧困者への責任帰属が増していること等を示寸も のもある[橋本 12]. さらに, 帰属ラベルに「責任」を用 いるとテロ，殺人，災害と行った条件で「隙」や「落ち 度」といったラベルと異なり, 条件間の差異は大きくな いこと[竹内 16]などがみられる.

これらは責任概念の二つの意味, タスク遂行責任と原 因として責めを負う責任のうち，前者を説明するもので ある。もちろん, 両者は関連するものであり, 双方向的 な関係にある. タスクを遂行するいわば倫理的な義務が 社会秩序の要請により法的な責任になることもあり，ま た, 社会秩序の要請があって法的規範ができてそれが倫 理的な義務として浸透していくこともある. 本研究は, こうした責任概念に関する前者の認識を解明しようとす るものである. その際, 責任帰属に関する先行研究で, 例えば, 責任帰属の考え方として, 自らも適用される可 能性のある道徳規準を他者に適用寸ることのリスクが勘 案されていること, あるいは, 結果がポジティブで便益 がある場合には当事者とは負の相関として考えられるこ となどのように，費用・リスク又は便益が責任帰属意識 の要素であることが示されていることを用いて, タスク 遂行責任についての一般の者の認識を構成する内容を明 らかにしようとするものである. 人工知能を含む知的な 機械・システムに対する将来の責任帰属性に関する現時 点での一般の者の認識を示し, 高度情報社会における責 任概念の実態を把握することを目的としている.

\section{3. アンケート調査の概要}

この研究の基本データとして用いるアンケート調查 の概要は[江間 16a, Ema 16b]において説明されている. 調 查対象と期間は, 2015 年 12 月 1 日から 7 日及び 2016 年 12 月 3 日から 7 日に，それぞれ，年齢を 20 代から 60 代 をほぼ等分に, 一般モニター男女 250 名ずつの Webアン ケートの回答 (回答者が Web サイトにアクセスして回答 するWebアンケート) を集計したものである. 回答率は $7 \sim 30 \%$ 程度であり, 2 回目の調査の回答状況を例示する この研究は,このデータを用いた二次分析の論文である. 20 代回答者の回答率が一桁であること, 代表性の問題等 Web 調查の問題などについては, 調査できなかった者の 偏りが必ずしも排除できないとはいうものの，責任概念 に関する特定の考え方を持っている集団だけを除いてい るとは考えられないことから，この点に留意しつつ，以 下検討を進めることとする. 
(表 1 : 回答状況（2016 年調査)）

\begin{tabular}{|c|c|c|c|c|c|c|}
\hline \multirow[b]{2}{*}{ 回答者属性 } & \multirow[b]{2}{*}{$\begin{array}{c}\text { 配信数 } \\
\text { (A) }\end{array}$} & \multirow[b]{2}{*}{$\begin{array}{c}\text { 回答数 } \\
\text { (B) }\end{array}$} & \multicolumn{3}{|c|}{ 回答数日別内訳 } & \multirow{2}{*}{$\begin{array}{c}\text { 回答率 } \\
(\mathrm{B}) /(\mathrm{A}) \\
(\%)\end{array}$} \\
\hline & & & $\begin{array}{l}2016- \\
12-03\end{array}$ & $\begin{array}{l}2016- \\
12-04\end{array}$ & $\begin{array}{l}2016- \\
12-05\end{array}$ & \\
\hline 男性/20代 & 674 & 50 & 34 & 13 & 3 & $7.4 \%$ \\
\hline 男性/30代 & 336 & 50 & 37 & 7 & 6 & $14.9 \%$ \\
\hline 男性/40代 & 226 & 50 & 27 & 11 & 12 & $22.1 \%$ \\
\hline 男性/50代 & 184 & 50 & 34 & 12 & 4 & $27.2 \%$ \\
\hline 男性／60代以上 & 162 & 50 & 30 & 11 & 9 & $30.9 \%$ \\
\hline 女性/20代 & 672 & 50 & 36 & 11 & 3 & $7.4 \%$ \\
\hline 女性／30代 & 388 & 50 & 27 & 15 & 8 & $12.9 \%$ \\
\hline 女性 /40代 & 276 & 50 & 29 & 13 & 8 & $18.1 \%$ \\
\hline 女性／50代 & 216 & 50 & 24 & 13 & 13 & $23.1 \%$ \\
\hline 女性／60代以上 & 166 & 50 & 23 & 12 & 15 & $30.1 \%$ \\
\hline 合計 & 3300 & 500 & 301 & 118 & 81 & $15.2 \%$ \\
\hline
\end{tabular}

この調査で得られた結果としては，全体として運転・ 防災・軍事分野など「知的な機械・システム」の導入に社 会的合意が必要とされる分野の機械化には積極的な意見 が多かったが，一方で，ライフイベントにおける意思決 定や健康管理など個人選択に委䄈られる分野は「人間が 主体で機械を活用する」傾向にあった.

この調査においては，先にも触れたが，意味が一意に 定まらない人工知能という単語は用いず，人の状態や希 望を自動で察知・判断し, 先回りして必要な情報などを 提供するサービスを「知的な機械・システム」と定義し， この「知的な機械・システム」に対し，運転や育児など の分野で人間がどの程度仕事を委任できるかを調べてい る.

また，2015 年と 2016 年調査の比較を中心にした[科学 技術振興機構 17]では，「知的な機械・システム」の理解 は未だ十分に進んでいないこと， 2015 年と 2016 年で大 きな変化はなかったこと, 及びA I 開発原則の利用者側 からの倫理面とアカウンタビリティ面についての理解の 拡大が必要であることなどをまとめている。 また, クロ
ス集計においては，育児経験がある方が人間主体で行う 意見，介護経験があると A I を活用する意見，車必須の 人は人間主体の意見, 創作経験がないと人間主体の意見 が多いとされている。

\section{4. 分析モデル·結果}

\section{1 知的な機械·システムを責任主体とすべきでない か}

アンケートデータを活用した分析の中でも主観デー タで主観データを説明する分析は，客観的行動を説明す るものとはなりにくい，これは，主観を決定する要因に 他の様々な要因の影響を排除しにくく，また，決定プロ セスも解明しにくいためでもある[富岡 06].ここでは客 観データである性別，年齢，育児経験，介護経験，車の 必須性, 創作活動経験, 最終学歴, 所属組織形態, 職位, 所属学会を説明変数としている. 被説明変数として, 責 任概念を構成する要素の中で関連する幾つかの主観的認 識とどのように関わってくるかを見る，具体的には，表 2 左の運転, 育児, 介護, ライフイベントにおける意思 決定，健康管理，創作活動，防災活動及び軍事活動に関 して，機械に任せるべきではないとする選択理由を選ん だ者について回帰している.

このアンケート調査においては，知的な機械・システ ムとの関係を 8 つ側面に分けて, それぞれについて, そこへの人間の関わり方への認識を選択肢とその理由に 基づいてデータ化している. その各区分と選択肢，そし てその理由は次の表 2 のおりである.
(表 2 : 区分と選択肢)

\begin{tabular}{|l|l|l|}
\hline & 関係 & 内容 \\
\hline 1 & 運転 & \multicolumn{2}{|c|}{$\begin{array}{l}\text { ハンドル操舵, 速度制御, ナビゲーション, 縦列駐車, } \\
\text { 突回避等 }\end{array}$} \\
\hline 2 & 育児 & \multicolumn{2}{|l|}{ 遊び相手, 寝かしつけ, 見守り, 食事, 入浴, しつけ等 } \\
\hline 3 & 介護 & 排泄, 入浴, 食事, 移乗, 話し相手等 \\
\hline 4 & $\begin{array}{l}\text { 自己のライフイベントにお } \\
\text { ける意思決定や判断 }\end{array}$ & $\begin{array}{l}\text { 進学, 就職・転職, 結婚・離婚, 妊娠 } \\
\text { 出産, 相続・終活 }\end{array}$ \\
\hline 5 & 自分の健康管理・ヘルスケア & 食事, 運動, 睡眠, 喫煙, 飲酒 \\
\hline 6 & 創作活動 & 音楽, 絵画, 小説, ゲーム制作 \\
\hline 7 & 防災活動 & $\begin{array}{l}\text { 救護・救助, 創作・探索, がれき処理, 物流支援, 被害 } \\
\text { 予測等 }\end{array}$ \\
\hline 8 & 軍事活動 & $\begin{array}{l}\text { 偵察, 警備 }(\text { 見張り), 戦闘行為, スパイ, 防諜, 救助, } \\
\text { 物流支援 }\end{array}$ \\
\hline
\end{tabular}

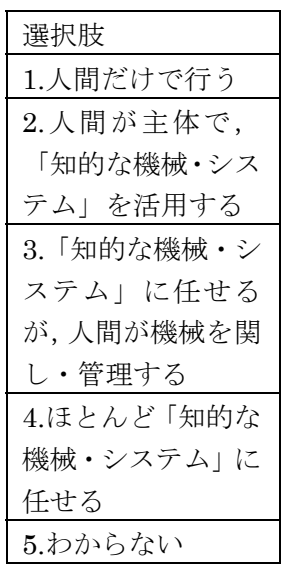

\begin{tabular}{|c|}
\hline 理由 \\
\hline $\begin{array}{l}\text { 1.よりミスが少なくなる } \\
\text { から }\end{array}$ \\
\hline 2.より現実的だから \\
\hline 3.より信頼できるから \\
\hline $\begin{array}{l}\text { 4.より便利で楽そうだか } \\
\text { ら }\end{array}$ \\
\hline $\begin{array}{l}\text { 5.人間が行うもので, 機 } \\
\text { 械に任せるべきもので } \\
\text { はないから }\end{array}$ \\
\hline $\begin{array}{l}\text { 6.プライバシー情報の管 } \\
\text { 理が心配だから }\end{array}$ \\
\hline $\begin{array}{l}\text { 7.その他: 具体的 (事由記 } \\
\text { 述) }\end{array}$ \\
\hline
\end{tabular}


（表 $3:$ 機械に任せるべきでない区分への属性別影響度）

\begin{tabular}{|c|c|c|c|c|c|c|c|c|}
\hline & 運転 & 育児 & 介護 & ライフイベント & 健康 & 創作 & 防災 & 軍事 \\
\hline 育児経験有り & -0.148 & -0.288 & 0.164 & -0.195 & 0.144 & 0.239 & 0.180 & 0.341 \\
\hline 介護経験有り & 0.115 & $-0.103 * *$ & 0.151 & -0.020 & -0.200 & -0.014 & -0.031 & 0.095 \\
\hline 車必須 & 0.035 & -0.134 & -0.048 & -0.111 & -0.108 & 0.043 & $0.184 *$ & -0.092 \\
\hline 健康管理重視 & -0.054 & -0.235 & -0.184 & $-0.253 *$ & -0.158 & 0.031 & 0.236 & 0.074 \\
\hline 創作経験有り & 0.467 & 0.229 & 0.083 & $0.568 * *$ & $0.550 *$ & -0.009 & 0.541 & 0.300 \\
\hline 大卒 & -0.135 & 0.027 & -0.123 & 0.065 & 0.106 & $0.305^{* *}$ & 0.082 & 0.176 \\
\hline 年齢 & 0.024 & -0.039 & -0.003 & 0.063 & 0.045 & $0.104 * *$ & -0.062 & -0.054 \\
\hline 性別 & -0.099 & $0.295 * *$ & -0.181 & $0.469 * * *$ & 0.062 & 0.220 & -0.081 & 0.085 \\
\hline 2016年調査 & -0.076 & $-0.300 * *$ & -0.221 & $-0.346 * * *$ & -0.088 & $-0.231 *$ & -0.102 & 0.103 \\
\hline 定数項 & $-2.112 * * *$ & 0.203 & $-0.976 * *$ & $-0.671 *$ & $-1.262 * * *$ & $-1.167 * * *$ & $-2.518 * * *$ & $-2.429 * * *$ \\
\hline Observations & 1000 & 1000 & 1000 & 1000 & 1000 & 1000 & 1000 & 1000 \\
\hline Log likelihood & -425.99 & -679.53 & -571.59 & -672.04 & -629.83 & -660.14 & -350.45 & -377.03 \\
\hline McFadden R-squared & 0.004 & 0.018 & 0.006 & 0.030 & 0.008 & 0.012 & 0.012 & 0.009 \\
\hline Akaike info criterion & 0.872 & 1.379 & 1.163 & 1.364 & 1.280 & 1.340 & 0.721 & 0.774 \\
\hline
\end{tabular}

（表中の記号は次の $\mathrm{p}$ 值の值を示すものである.***: $<<0.01 ， * * \mathrm{p}<0.05, *:<0.1 . \quad$ 以下の表で同じである.)

選択肢は人間と知的な機械・システムの関与の仕方に ついて濃淡が設けられている。そして，これを回答した 上で，その理由として，よりミスが少なくなる等幾つか の理由が挙げられており複数回答可とされている．ここ では，そのうち特に「人間が行うもので，機械に任せる べきものではないから」とする理由がどれだけ選ばれて いるかを，知的な機械・システムは責任主体とすべきで ないと認識していることの基準とみなす。すなわち, 責 任帰属に関する先行研究を踏まえ, 直接の費用・リスク 又は便益が責任の認識に反映していると考え, 知的な機 械・システムは責任主体とすべきとする意識は，防災や 軍事では責任との関連が強くなく, 育児や介護では強い のではないかとの仮説を設定するものである.

ここでの質問への回答は複数回答可で，順序が付いて いないものである.このため, 2015 年・2016 年調査につ いてこの理由の選択に関しダミー変数 $(D)$ を用いて次の ロジット推定式で推計を行った.

$$
\operatorname{logit}\left(D_{i}\right) \equiv \log \left(\frac{p}{1-p}\right)=\alpha_{1}+\beta_{1} H_{i}^{*}+\gamma_{1} X_{i}+\varepsilon_{i}
$$

ここで $p$ はその事象が選ばれる確率を意味するもので, この調査ではその理由を選択したかしなかったかの観測 に対して $\alpha_{1}, \beta_{1}$ 及び $\gamma_{1}$ を最尤法によって推定すること ができる，ここで，添字 $i$ は各回答者を表し， $H_{i}{ }^{*}$ は主観 的な経験の有無, $X_{i}$ でその他の外生的な説明変数のべク トル（年齢以外はダミー変数）を表すものとし， $\varepsilon$ は詿 差項とする.

ここで説明変数として用いているものは，育児経験の 有無，介護経験の有無，生活に車が必須かどうか，健康 管理に気を配っているか, 音楽絵画小説等創作経験の有 無，大卒かどうかをそれぞれ有り $=1$ ，無し $=0$ とした ダミー変数である．また，年齢は 20 代〜60 代をそれぞ れ $1 \sim 5$, 性別は男性 $=0$, 女性 $=1 ， 2016$ 年調查の項 は 2015 年調查 $=0,2016$ 年調查 $=1$ とした変数である. 被説明変数は，機械に任せるべきではないとする選択理 由を選んだ者を 1 ，選ばなかった者を 0 としている。

結果は表 3 のとおりである。統計的に有意な関係を有
していたものは, (1)介護経験を有する者で, 男性で, 2015 年調査の方が，育児に関しては人間が行うもので機械に 任せるべきものではないとする者の割合が少なかったこ と, (2)創作経験がある者で, 男性で, 2015 年調査の方が, ライフイベントに関しては人間が行うもので機械に任せ るべきものではないとする者の割合が多かったこと，及 び，(3)大卒で，年齢が高い者の方が，創作活動に関して は人間が行うもので機械に任せるべきものではないとす る者の割合が多かったこと，が挙げられる.

この結果について次の 3 つの含意が考えられる．第一 に，区分の特徴として，防災・軍事はともに経済学用語 での公共財としての性格を有する財であり，いわゆる非 排除性と非競合性を持つ財である。これらを公共的なサ 一ビス全てのものとして一般化することはできないが， 公共財の特性として，便益は認識しやすいが個別費用負 担は考えにくいということは注目できる。このため，機 械に任せたときに生じかねない費用，リスク，そして責 任は考えにくいため，機械に任せるべきかどうかといっ た知的な機械・システムの責任について意識を持ちにく いとも考えられる.第二に, 育児に関して女性が, 又は, 創作に関して大卒で年齢が高い者の方が，機械に任せる べきでない（人間が行うもの）とする者の割合が多い. このことは，一般的に，育児を担うことが多い女性（[少 子化対策白書 17] 女性の育児時間が長いことが挙げら れている.)，創作に関する自由度がより高くなるとされ る大卒・年齢が高い者（[国民生活に関する世論調査 17] 年齢が高い者の余暇時間が多いことが挙げられている.) にとって，責任を人間が負うことになるリスク・費用よ りも，そこに携わる便益がより大きくなるためとも考え られる．これらの面で，当初の仮説は成り立っていると 考えられる. 第三に, 経験財としての性格を有する育児・ 介護・健康管理・創作は，それぞれ従事しないと意見を 持ちにくい部分もあるかもしれないとも考えられる。し かしながら，それらの経験が直接関連する区分について の機械への意識について特定の方向（経験ある者は機械 に任せるべきと考えるか，あるいはその逆の意識を持つ 
か等）を示すものではない。

\section{2 検証 $1:$ 公共財への知的な機械-システムの関与}

公共財とは，非排除性と非競合性という特徵を有する ものである。非排除性とは, その財・サービスの利用に 対価を支払わない人を排除できないことである。非競合 性とは，対価を支払って購入しても独り占めできないこ とである，例外はあるものの，防災や軍事はその典型例 として挙げられることが多い. 公共財はこの 2 つの性質 から供給に当たっての費用負担の算定が容易でない．知 的な機械・システムの利用に際しての責任の議論は費用

（リスクも含む）負担とも関連する。このため, 直接費 用負担を感じにくい公共財に対しては, 属性別の責任の 意識は強くない. したがって，属性別で見たときの有意 となるものが生じなかったと考えられる.

これを検証するために, 被説明変数全体をプールして 推計し, その中の防災と軍事の区分の特徵を検証してい る. その結果が次の表 4 のとおりである（推計式は (1) と同様のもので，区分を全体でプールして，被説明変数 を機械に任せるべきでないダミーとし，各区分ごとにダ ミーを取った。ベースは車が必須である区分とした。）。

表 4 の結果によると, 防苂と軍事についての利用, こ こでいういわゆる公共財の区分だけが，他の区分（育児・ 介護・ライフイベント・健康管理・創作）での機械に任 せるべきかどうかについての認識とは符号が逆転して有 意となっている. 寸なわち，これらの区分は人間が行う ベきで機械に任せるべきではないとする認識は強くない

（仮説を裏付ける結果が出た）と考えられる.

（表 4：公共財への属性別影響度）

\begin{tabular}{|c|c|c|}
\hline \multicolumn{3}{|c|}{ 被説明変数: 機械に任せるべきでないダミ一 } \\
\hline 育児経験有り & 0.026 & \\
\hline 介護経験有り & -0.024 & \\
\hline 車必須 & -0.044 & \\
\hline 健康管理重視 & -0.102 & * \\
\hline 創作経験有り & 0.312 & $* * *$ \\
\hline 大卒 & 0.068 & \\
\hline 年歯令 & 0.019 & \\
\hline 性別 & 0.141 & $* * *$ \\
\hline 2016 年調査 & -0.193 & $* * *$ \\
\hline 育児区分ダミ一 & 1.573 & $* * *$ \\
\hline 介護区分ダミー & 0.656 & $* * *$ \\
\hline ライフイベントダミー & 1.654 & $* * *$ \\
\hline 健康管理ダミ一 & 0.999 & $* * *$ \\
\hline 創作ダミ一 & 1.240 & $* * *$ \\
\hline 防災ダミ一 & -0.343 & $* * *$ \\
\hline 軍事ダミ一 & -0.240 & * \\
\hline 定数項 & -2.018 & $* * *$ \\
\hline Observations & 8000 & \\
\hline Log likelihood & -4414 & \\
\hline McFadden R-squared & 0.087 & \\
\hline Akaike info criterion & 1.108 & \\
\hline
\end{tabular}

\section{3 検証 2 : 責任帰属既存研究との異同}

育児に関して女性が，又は，創作に関して大卒で年齢 が高い者の方が，機械に任せるべきでない（人間が行う もの）とする者の割合が多かった。このことは，一般的 には，育児時間が長く，また，男性より平均的に賃金が 低く育児での機会費用の損失が小さい状況にある女性は, 男性に比べ, 人間が責任を担い得ると感じられたためと 考えられる，同様に，創作に関する自由度がより高くな る大卒や年齢が高い者にとって, 創作に携わる便益が大 きいためと考えられる.

これまでの責任帰属研究で, 主として, 自己の心理学 的な安寧を維持しようとする自己防衛的動機付け（防衛 的帰属理論), 当事者と判断者との環境条件間の類似性を 意味する状況的関連性と, 何らかの個人的特徵での類似 性を意味する個人的関連性とを区別する関連性理論など, 多様な検討が行われてきているが，共通する考え方とし て，費用とリスクが大きくなるときには責任を取りたく ないとする（ポジティブの場合は逆となる）枠組みが用 いられている.これをこのデータに当てはめて検証する. このために, 理由の選択肢における,「より便利で楽そう だから」とする者が「人間が行うべきもので，機械に任 せるべきものではないから」とする者と逆の傾向を示し ているかどうかを検証する．すなわち，より便益を受け そうな者は人間が行うべきと考えており, それは便利で 楽そうになると強められるかを検証するものである.

推計式は（1）と同様のもので，被説明変数を「より 便利で楽そうだから」を選んだかどうかのダミーとして 推計を行った。

結果は表 5 のとおりである.

（表 5 : 便利で楽そうという認識）

\begin{tabular}{|c|c|c|c|c|}
\hline \multicolumn{2}{|r|}{ 育児 } & \multicolumn{3}{|c|}{ 創作 } \\
\hline 育児経験有り & 0.465 & & -0.041 & \\
\hline 介護経験有り & 0.110 & $* *$ & 0.176 & \\
\hline 車必須 & 0.244 & & -0.202 & \\
\hline 健康管理重視 & -0.258 & & -0.292 & * \\
\hline 創作経験有り & -0.032 & & 0.161 & \\
\hline 大卒 & 0.353 & & -0.299 & * \\
\hline 年齢 & 0.019 & $* *$ & 0.011 & \\
\hline 性別 & 0.392 & & 0.181 & \\
\hline 2016年調査 & -0.078 & $* *$ & -0.265 & * \\
\hline 定数項 & -2.354 & $* * *$ & -1.042 & $* *$ \\
\hline Observations & 1000 & & 1000 & \\
\hline Log likelihood & -450.42 & & -556.71 & \\
\hline McFadden R-squared & 0.022 & & 0.016 & \\
\hline Akaike info criterion & 0.921 & & 1.133 & \\
\hline
\end{tabular}

表 5 の結果によると，育児に関しては女性が正の係数 ではあったが有意ではなかった。また，創作に関しては 大卒で負の $10 \%$ 有意の係数となり, 年齢は有意ではなか った，すなわち，育児に関しては女性である係数が正で 
あったため，知的な機械・システムは便利で楽そうだと する認識を有する傾向がみられた。 また, 創作に関して は大卒の係数が負で弱く有意であったため便利になるも のではないという認識を有するものであったとみること ができる。したがって，育児に関し女性は人間が行う心゙ きで機械に任せるべきではないことを補完する意味で, 便利で楽そうなものを歓迎する傾向があり,創作に関し， 自由度の高いと思われる大卒は人間が責任を担うべきで, 費用は掛かり得る(楽そうだから機械に任せるのでない) が，人間が行うことそのこと自体に便益が生じていると の認識が示されているとも考えられる。したがって, 直 接の費用・リスク又は便益が認識に反映していることに なり, この面でも, 当初の仮説を裏付ける結果が出たと 考えられる。

\section{4 検証 3 : 責任主体についての意識(内生性のチェ ック)}

ここまでの検討は，知的な機械・システムに対する認 識は, ある者の属性と双方向の関係を有しているとする いわゆる相関関係をみている。具体的には，例えば，「育 児経験がある者」が「育児は知的な機械・システムに任 せるべきではない」と認識しているだけでなく,「育児は 知的な機械・システムに任せるべきではない」と認識し ている者が「育児経験」を有していることも検討してい ることになる。ここで, 前者 (属性) が後者 (認識) に 与えている影響を見ようとすると, この相関関係が双方 向に影響を及ぼしている可能性があるため, 育览経験有 りと誤差項の間に正の相関が生じてくる，そこで，属性 の認識への影響を見るために, 操作変数法を利用するこ とで，この問題に対処する. 具体的には，主観的な人間 の関わり方の水準を外生変数と識別変数 $Z_{i}$ を用いて線形 予測值を求め、その予測值を(1)式の $H_{i}{ }^{*}$ 之置き換えて次 の(2)式で推計する（[松島 16]参照）.

$$
H_{i}^{*}=\alpha_{2}+\beta_{2} X_{i}+\gamma_{2} X_{i}+\varepsilon_{i}
$$

ここで，識別変数 $Z_{i}$ には，育児の区分であれば，「10 年後の 2015 年の様々な社会の場面を想像したときに」, 回答者が受け入れ可能だと考える人間と「知的な機械・ システム」の関係に一番近い選択肢を選ぶ質問に対して, 「人間だけで行う」,「人間が主体で『知的な機械・シス テム』を活用する」, 「知的な機械・システム』に任せる が，人間が機械を関し・管理する」，「ほとんど知的な機 械・システムに任せる」を 1 〜 とし,「わからない」は 除いている.この結果が表 6 のとおりである.
（表 6 : 内生性を考慮した推計）

\begin{tabular}{|c|c|c|c|c|}
\hline & 育児 & & 介護 & \\
\hline 育児経験有り※ & -19.625 & $* * *$ & -6.754 & $* *$ \\
\hline 介護経験有り※ & 1.488 & $* * *$ & 108.734 & $* * *$ \\
\hline 車必須 & 3.467 & $* * *$ & -4.748 & \\
\hline 健康管理重視 & 0.728 & $* * *$ & -1.276 & $* *$ \\
\hline 創作経験有り & -0.351 & & -15.030 & $* * *$ \\
\hline 大卒 & -0.437 & $* * *$ & -0.404 & $* *$ \\
\hline 年齢 & -2.166 & $* * *$ & 5.994 & $*$ \\
\hline 性別 & -0.990 & $* * *$ & 5.384 & $*$ \\
\hline 2016年調査 & -1.347 & $* * *$ & -5.703 & $3 *$ \\
\hline 定数項 & 17.824 & $* * *$ & -89.260 & $*$ \\
\hline Observations & 864 & & 871 & \\
\hline Log likelihood & -511.17 & & -439.40 & \\
\hline McFadden R-squared & 0.146 & & 0.113 & \\
\hline Akaike info criterion & 1.206 & & 1.032 & \\
\hline
\end{tabular}

（※は内生性を考慮した後の操作変数法での数值）

この結果によると, 内生性を考慮した後の説明変数で ある「育児経験有り※」及び「介護経験有り※」の説明 力は上がり, 育児では機械に任せるべき, 介護では機械 に任せるべきでなく人間が行うべきと認識している者の 值が統計的に強く有意となった。それ以外の説明力も向 上し，大卒でないことはともに機械に任せるべきでない ことを表すものになったが，それ以外では逆の方向を示 すものとなった．したがって，ここまで見てきた相互の 関倸は内生性を考慮した後でも妥当するものであり，当 初の仮説を補強するものとなっている.

\section{5. 考察·結論}

本研究は, 責任帰属に関する先行研究を踏まえつつ, 人工知能を含む知的な機械・システムに対する将来の責 任帰属性に関する現時点での認識を明らかにしようとし た.この際, 人の状態や希望を自動で察知・判断し, 先 回りして必要な情報などを提供するサービスを「知的な 機械・システム」と定義し，それに対して人間がごの程 度仕事を委任できるかを調べたものであった。推計して, 検証できた結論としては，(1)防災・軍事といった，いわ ゆる公共財に対しては人間が行うべきで機械に任せるべ きではないとする認識は強くない, (2)既存研究を裏付け るとおり，育児に関し，育児での機会費用の損失が小さ い状況にある女性は，男性に比へ，人間が責任を担い得 るという認識が多く示された。他方, 創作に関し, 自由 度の高いと思われる大卒は, 人間が責任を担うべきで, 費用は掛かり得る（=楽そうだから機械に任せるのでな い）が，人間が行うこと自体で便益が得られるとの認識 が示された。 (3)内生性を考慮した後の育览経験と介護経 験に関しては, 育児経験のある者は育児について機械に 任せるべきでないと, 介護経験のある者は介護について 機械に任せるべきとする認識を強めた結果が示された。

この結果のインプリケーションとしては, 第 1 に, 知 
的な機械・システムに対する人々の捉え方, 責任帰属は, それを用いる際の財・サービスの区分によって異なって 認識されている. 公共財に対しては, 特段の選好を有し ておらず，育児は人間が行うべき，介護は利用すべきと いった違いが存在している.ただし, 公共財（いわゆる 公共財は，公共サービス全般とは別の概念であり，非排 除性と非競合性を有する財である）としての特徽を有す る財・サービスについての意識の一般化については更な る分析が必要であることには留意すべきである.第 2 に, 知的な機械・システムの責任を考える際に, それらの財・ サービスに掛かる費用とそのリスクがその責任帰属判断 における一定の要素となっている可能性が示唆された. 第 3 に, 高度情報社会における責任概念は様々な要素で 構築されており, 科学技術の応用の局面とそこでの費用・ リスクといった状況を踏まえた上で, 人々の認識を丁寧 に検討していくことが必要であることが明らかにされた ことだと考えられる.こうした点で, 社会の実態調査は, 意識調査だけでなく科学技術の応用場面の経済的状況の 把握も併せて行って評価していくことが必須と考えられ よう. なお, ここで, このアンケート調查を用いて結果 をまとめるに際して, このアンケート調査は責任概念そ のものを直接問うた質問となっていないことから，この 結果の解勫において一定の留保が必要である. 加えて, 倫理的な側面と表裏一体の関係にある法的な責任につい ても今後検討を進めることが課題である.

この責任概念の分析からの人工知能研究の倫理面の 検討への貢献は, 次の点が挙げられる. いわゆる公共財 においては，責任帰属に関する認識が強くない状況で人 工知能等の利用が進むと考えられるため, 倫理指針の丁 寧な適用が必要である. 他方, 費用対効果のイメージし や寸い財・サービスでの人工知能の利用は，情報開示の 下，選択肢の提示に基づく利用者責任での展開が期待さ れる. 今後の人工知能の免許 - 保険等の議論に向けて, 現時点において各般の考慮要素を示した倫理指針の策 定・公表は時宜にかなった取組とも考えられる.

謝辞 本研究は,「人と情報のエコシステム」プロジェク 卜企画調查「高度情報社会における責任概念の策定」に おける議論に基づいている. 研究会の参加者に謝意を表 したい. また, データの利用に関しては, JST-RISTEXの 茅明子さんの御協力に感謝したい.

\section{$\diamond$ 参考文献 $\diamond$}

[江間 16a] 江間有砂, 秋谷直矩, 大澤博隆, 服部宏充, 大家 慎也, 市瀬龍太郎, 神崎宣次, 久木田水生, 西條玲奈, 大谷卓史, 宮野公樹, 八代嘉美. 運転 - 育児・防災活 動, どこまで機械に任せるか. 情報管理, Vol. 59, No. 5, pp. 322-330. (2016)

[Ema 16b] Ema, A., Akiya, N., Osawa, H., Hattori, H., Oie, S., Ichise, R., Kanazaki, N., Kukita, M., Saijo, R., Otani, T., Miyano, N., and Yashiro, Y. Future relations between humans and artificial intelligence - A stakeholder opinion survey in Japan. IEEE Technology and Society Magazine, Vol. 35, No. 4, pp. 68-75. (2016)

[橋本 12] 橋本剛明, 白岩祐子, 唐沢かおり. 経済格差の是正 政策に対する人々の賛意 : 機会の平等性と社会階層の認 知が責任帰属に与える影響の検討. 社会心理学研究, 第 28 巻第 1 号, pp. 13-23. (2012)

[人工知能学会倫理委員会 17 ] 人工知能学会倫理委員会. 人工知 能学会倫理指針. (2017). URL http://ai-elsi.org/wpcontent/uploads/2017/02/\%E4\%BA\%BA\%E5\%B7\%A5\%E 7\%9F\%A5\%Е8\%83\%BD\%E5\%AD\%A6\% $\mathrm{E} 4 \% \mathrm{BC} \% 9 \mathrm{~A} \% \mathrm{E}$ $5 \% 80 \% \mathrm{AB} \% \mathrm{E} 7 \% 90 \% 86 \% \mathrm{E} 6 \% 8 \mathrm{C} \% 87 \% \mathrm{E} 9 \% 87 \% 9 \mathrm{D}$.pdf

[科学技術振興機構 17] 科学技術振興機構. 「超スマート社会 の社会受容性調查」の一般モニタアンケート調查結果. 人と情報のエコシステム（HITE）」領域合宿資料. (2017)

[国民生活に関する世論調查 17] 内閣府大臣官房政府広報室 (2017) URL http://survey.gov-online.go.jp/h29/h29life/index.html

[松島 16] 松島みどり, 立福家徳, 伊角彩, 山内直人. 現在の 幸福度と将来一の希望一-幸福度指標の政策的活用. 日 本経済研究, Vol. 73, pp. 31-56. (2016)

[諸井 88] 諸井克英. 防衛的帰属理論に関する実験的研究：交 通事故の当事者に関する責任判断を中心として. 人文論 集. Vol. 38, pp. A33-A74. (1988) URL http://doi.org/10.14945/00003887

[Shaver 70] Shaver, K. G. Defensive attribution: Effects of severity and relevance on the responsibility assigned for an accident. Journal of Personality and Social Psychology, Vol. 14, pp. 101-113. (1970)

[少子化対策白書 17] 内閣府子ども・子育て本部 (2017) URL http://www8.cao.go.jp/shoushi/shoushika/whitepaper/m easures/w-2017/29pdfhonpen/29honpen.html

[白岩 12] 白岩祐子, 宮本聡介, 唐沢かおり。犯罪被害者に対 するネガティブな帰属ラベルの検討 : 被害者は「責任」 を付与されるのか. 社会心理学研究, 第 27 巻第 2 号, pp. 109-117. (2012)

[竹内 16] 竹内穂乃佳, 釘原直樹. 災害 被害者の責任帰属につ いて検証被害者の責任帰属について検証 被害者の責任 帰属について検証一テロは殺人と違うのか. 対人社会心 理学研究, Vol. 16, pp. 27-32. (2016)

[富岡 06] 富岡淳. 労働経済学における主観的データの活用. 日本労働研究雑誌, Vol. 551, No. 6, pp. 17-31. (2006)

[Walster 66] Walster, E. Assignment of responsibility for an accident. Journal of Personality and Social Psychology, Vol. 3, pp. 73-79. (1966)

〔担当委員 : 高橋 恒一]

2017 年 3 月 16 日 受理
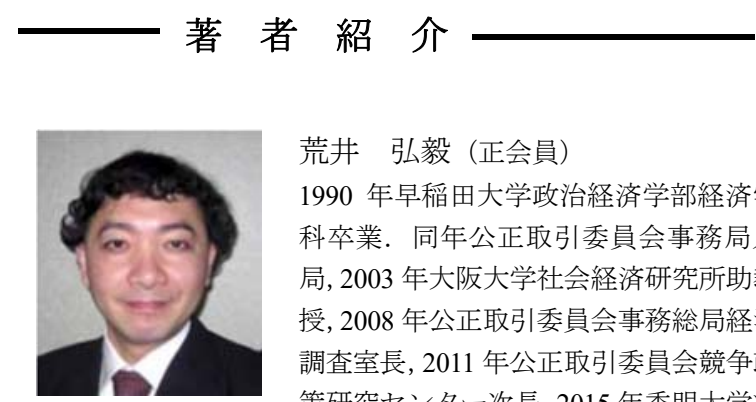

荒井 弘毅（正会員）

1990 年早稲田大学政治経済学部経済学 科卒業. 同年公正取引委員会事務局入 局, 2003 年大阪大学社会経済研究所助教 授, 2008 年公正取引委員会事務総局経済 調查室長, 2011 年公正取引委員会競争政 策研究センター次長, 2015 年秀明大学総 合経営学部教授. 博士 (経済学). 